\title{
Chapter 1 \\ Preconditions of Transforming the Educational Process by Applying Inclusive Education Strategies: Theoretical Background
}

\author{
Alvyra Galkienė (D) and Ona Monkevičienė (iD
}

\begin{abstract}
The experience of the development of inclusive education strategies in various countries has been the source of various conceptions and practices, which have gradually evolved into the axis of the education policy of the late twentieth and early twenty-first century. This chapter presents an overlook of insights that are significant for the practical implementation of inclusive education and substantiated by scientific research. As the perception of inclusive education developed from meeting special educational needs in general schools (Florian. Int $\mathbf{J}$ Incl Educ 23(7-8): 691-704. https://doi.org/10.1080/13603116.2019.1622801, 2019) to recognising the variety of needs of all students (Meyer et al. Universal design for learning: theory and practice. CAST, 2014), the Universal Design for Learning (UDL) approach was presented to the pedagogical circles. This chapter of the book examines the fundamental aspects of the UDL approach in the context of the development of the inclusive education construct, from emphasising the Zone of Proximal Development (Vygotsky. Thought and language. MIT Press, 1962) to highlighting the processes taking place in the inclusive education ecosystem (European Agency for Special Needs and Inclusive Education. Inclusive school leadership: exploring policies across Europe. (E. Óskarsdóttir, V. Donnelly \& M. Turner-Cmuchal, Eds.). Odense, Denmark. https://www.european-agency.org/sites/default/files/sisl_synthesis_report.pdf. Retrieved 16 April 2021, 2019), revealing the variety of perceptions of student uniqueness and education differentiation concepts in implementing inclusive education, and discussing the differences between the specificities of education goals and their implementation in the UDL and traditional approaches. The analysis of scientific research allowed us to distinguish the basic aspects of the UDL approach that are significant for the transformation of the traditional education system into a high-quality one based on the presumptions of success for every student and formed on the grounds of inclusive education.
\end{abstract}

\footnotetext{
A. Galkienè $(\bowtie) \cdot$ O. Monkevičienè

Educational Academy, Vytautas Magnus University, Kaunas, Lithuania

e-mail: alvyra.galkiene@vdu.lt; ona.monkeviciene@vdu.lt
} 
Keywords Inclusive education · Universal design for learning · Differentiation · Expert learner

\subsection{Transformational Aspects of Inclusive Education}

Inclusive education processes, begun alongside society's movement for the recognition of dignity and equal rights for all its members (Salend \& Garrick Duhaney, 2011), are, nevertheless, not the result of paradigm revolutions but rather of consistent societal evolution (Magnússon et al., 2019). However, it is not an automatic process. Inclusive education gains ground in school practices when it becomes a state priority sustained by solid, clear, and unambiguous national support and a unified perception of the phenomenon (Haug, 2020). The perception of inclusive education determines not only the characteristics of the education system but also the fate of the educated. As Ramberg and Watkins (2020) put it, major differences exist between European countries in terms of students' access to their right to inclusive education. In many cases, it is determined by the variety of conceptual education systems.

When analysing inclusive education concepts that serve as the basis for educational systems and the taxonomy of their development, it is worthwhile to remember the ideas of L. Vygotsky, born from pondering ways to help almost 7 million children suffering psychological trauma or physical injuries during World War I (Smagorinsky, 2012). Vygotsky (1993) defines two types of reasons limiting the quality development of a child with disability. These are primary reasons arising from biological differences in the body and secondary reasons stemming from the primary ones due to unfavourable social and cultural context restricting the social and cultural participation of the child with different needs and his or her possibility to realise his or her own potential: 'A physical defect somehow causes a social dislocation' (Vygotsky, 1993, p. 76). The analysis of contrasting education systems developed on the grounds of the ideas of Vygotsky allows a deeper understanding of the conceptual foundation of inclusive education, its development, and expression in the differing social and cultural contexts of different countries (Fig. 1.1).

Corrective Educational Model Although Vygotsky, when considering matters of education, never mentioned the concept of inclusion, he built the foundation for it by modelling education on the interaction of the person and their social and cultural environment, by linking the quality of life to reducing 'social displacement', and by criticising the corrective education model as well as the development of closed institutions based on this model. In Vygotsky's opinion (1924), it is necessary to recognise the powers of students with disabilities and cultivate them as the powers of all the other students are cultivated by eliminating the secondary reasons hindering the child's development. Society should create conditions favourable for the learning and educational as well as social and cultural participation of these students together with others, thus preparing them for the future of an employed adult. 


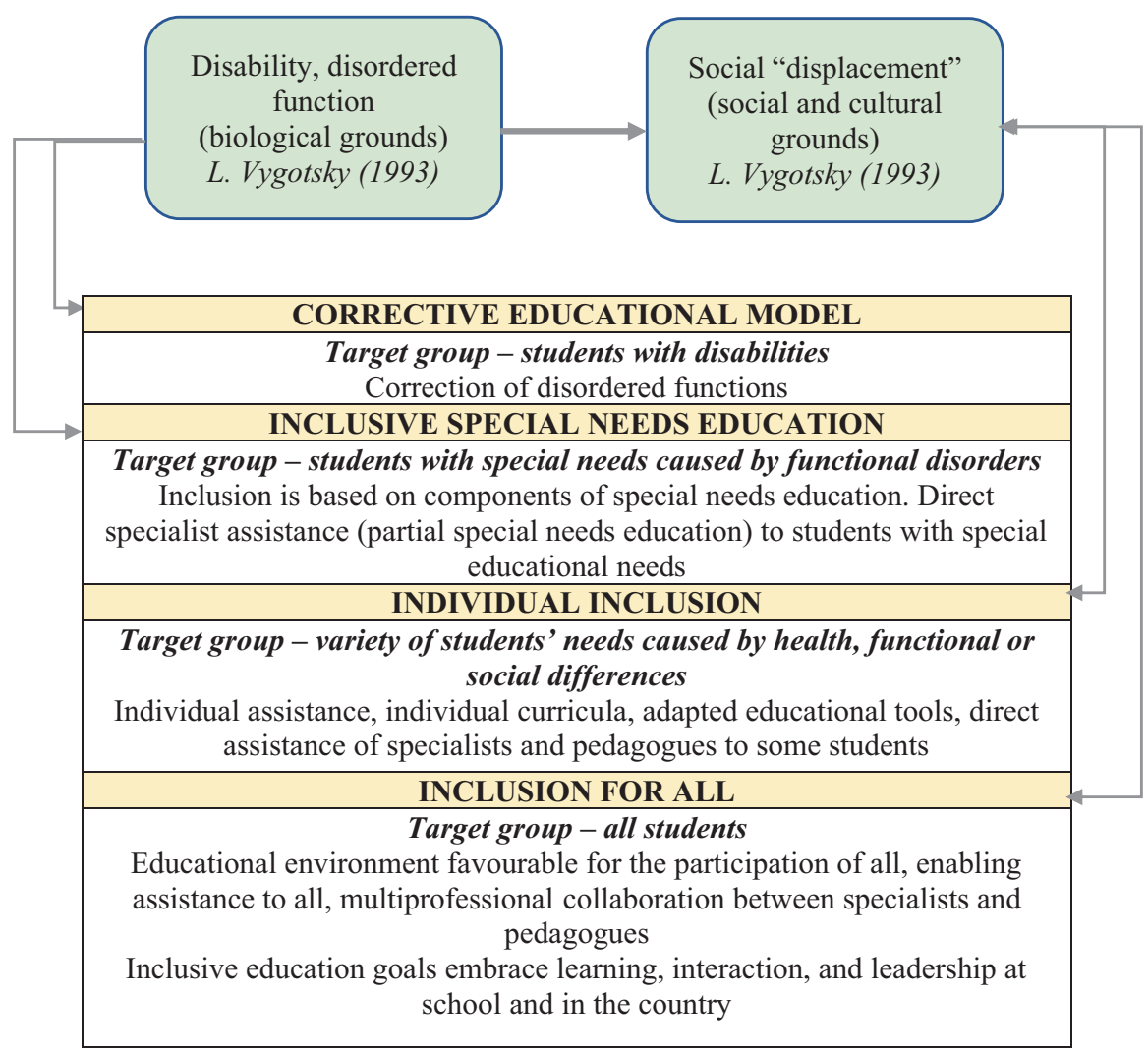

Fig. 1.1 Taxonomy of inclusive education

Despite Vygotsky's inclusive ideas, the corrective educational model was nevertheless vastly developed in the Soviet Union, following the main idea of overcoming or reducing the disorder and its consequences to the minimum, thus providing possibilities for the person to engage in public social and cultural life. Therefore, society itself adopted philanthropic roles, developing networks of specialised schools and jobs, and distributing support to people with disabilities (Smagorinsky, 2012).

Inclusive Special Needs Education After the Universal Declaration of Human Rights (UN General Assembly, 1948), an agreement to guarantee equal rights for all, attention was focused on the situation of individuals with disabilities in the system of education. It is natural that the system of special needs education $(\mathrm{Qu}, 2020)$, which was constructed following the prevailing medical approach to disability, was relocated to the system of general education. Hornby (2015) describes and bases this phenomenon on the concept of 'inclusive special needs education'. It is a practice targeted exclusively at students with special educational needs (SEN), based on the components of special needs education. Specialised schools are recognised as a 
more appropriate environment for the education of students with special educational needs (Buchner et al., 2021). The competency of the pedagogues is linked to special needs education. When considering the preconditions for the quality education of these students, the feasibility of sufficient competency development in general education teachers is questioned; therefore, the education of these students is entrusted to special needs teachers. Takala et al. (2009), having analysed the implementation of inclusive special needs education in Finland, when special needs teachers educate students with special educational needs in their separate rooms, conclude that such a model of education organisation is not favourable for developing inclusive education. Hornby (2015) notes that the concept of inclusive special needs education sees the inclusion of students as the goal of education, yet postpones its realisation for the future, after the graduation. Although the concept of inclusive special needs education includes the idea of inclusive education, the education is nevertheless designed based on disability and developmental disorders (Fig. 1.1).

Individual Inclusion After the world community agreed on the conception of inclusive education and this agreement was enshrined in the Salamanca Statement (UNESCO, 1994), inclusive education has become an educational policy effort in many countries (Ainscow, 2020). The concept of inclusion is expanded to include not only students with disabilities and functional disorders but also those facing difficulties due to differences resulting from their linguistic, cultural or social conditions. However, the conception of this education strategy, methodologies, and ways of its implementation to a great extent depend on the political, experiential, and cultural context of the country and are in the constant process of transformations. International research shows that in most European countries, inclusive education is identified with the teaching of SEN students in schools of general education (European Agency for Special Needs and Inclusive Education, 2019). However, the relationship between general education and special needs education still remains a problem (Magnússon et al., 2019; Florian, 2019). When students with different abilities and needs learn together with others, yet different forms or content of education are applied individually, or alternative curricula are used for 'some' students, this shapes experiences of stigmatisation and internal exclusion (Florian \& BlackHawkins, 2011). The current practice shows and the conducted research proves that the system of education, where the interaction between general and special needs education is not sufficiently balanced, tends to generate internal problems, such as incompliance between educational goals, curriculum, and students' abilities; in some cases, students' and teachers' negative attitude towards SEN students; difficulties related to their acceptance to the community; and problems of self-perception and self-assessment encountered by SEN students (Spencer \& Laurel, 2011). International research results show that the application of alternative curricula for students with special educational needs becomes an obstacle to their involvement and participation in the common educational experience (Hanreddy \& Östlund, 2020). Moreover, teachers encounter difficulties in differentiating educational content and implementing it individually for 'some' students (Westbroek et al., 2020). 
Inclusion for All The ideas of Booth and Ainscow (2002) saturated the conception of inclusive education with the priority of an inclusive education culture and emphasised the equal value of every student and staff member. This culture embraces not only interpersonal relations but also educational policy and practice. It is based on the principles of justice in education, the presence of which in a school, according to Ainscow and Hargreaves (2016), depends on numerous processes that reach the school from outside. Haug (2020) states that the consolidation of the position of inclusive education and justice in education relies on the development of inclusive culture and values directly in schools and the closest relationships around and indirectly - in the educational policy, when inclusive culture is acknowledged as a national priority.

The Global Education Monitoring Report 2020 (UNESCO, 2020) highlights the perception of inclusion that emerged in the fight of people with disabilities for their right to inclusive education, which continues to be linked to people with disabilities. However, inclusion is a phenomenon with a much broader scope. The same educational practice should involve not only people with disabilities but everybody, regardless of their age, gender, race, social, or ethnic background, place of residence, economic status, language, religion, sexual orientation, migration, and other circumstances. When implementing inclusion for all, one must acknowledge the signs of inequality and make an effort to eliminate them. One of these is the concept of 'special needs', which emphasises people's normality and deviations from the norm. In the perception of inclusion for all, this concept should be replaced by 'participation and obstacles to learning'.

However, when pursuing an inclusive and quality implementation of inclusion for all, it is obligatory to find solutions for students with mental disorders, most of whom still attend specialised schools (Buchner et al., 2021), principles of joint operation of specialists and teachers in building a flexible learning environment (Takala et al., 2009), and to eliminate obstacles for equal participation of all students (Ramberg \& Watkins, 2020).

The study 'Improving Inclusive Education Through a Universal Design for Learning' looks into the issue of improving inclusive education in the context of four European countries that all strive for a good quality inclusive education, yet have different social, cultural, and educational experiences and historic memory. The development of inclusive education began at the same time in all four countries, namely, at the end of the twentieth century, yet it followed different tracks. In Austria and Finland, the incentive to establish an inclusive education system within the state education system rose from a consistent societal evolution towards democratic relations. The transformation of the education systems was based on the model of inclusion for all and developed in the following way: in Finland-to include all the students, and in Austria-with particular focus on the educational inclusion of national and immigrant minorities. Whereas in Poland and Lithuania, the beginning of inclusion in the education systems coincides with the countries' political breakthrough, liberation from the Soviet regime, and a highly segregated system of special needs education. Inclusive education system was based on the 
model of individual inclusion, aiming to ensure the right for students with disabilities to learn under the conditions of inclusion (Galkienè, 2017).

The research presented in the study is based on the conceptual model of inclusion for all, as it is developed in the countries' education systems, applying the principles of the Universal Design for Learning (UDLP). The researchers follow the insight by Waitoller and Thorius (2016) stating that the interaction between the principles of pedagogy and the Universal Design for Learning (UDL) might prompt cultural pluralism, expand the perception of an expert learner as a reflecting and critically thinking student, encourage teachers' ability to recognise components that stigmatise students and promote exclusion, and build a barrier-free environment for the variety of students who come to their classrooms. For university teachers engaged in teacher training, the interaction might create conditions to continuously improve their inclusive education and UDL skills. Together, these components would lead to enhanced sustainability of inclusive education.

\subsection{Universal Design for Learning as a New Phenomenon in European Education}

Three decades ago, in 1990, Meyer et al. (2014), the developers of the UDL approach, concluded that in the traditional system of education, students encounter obstacles, which limit their accessibility to curriculum and the possibility of expressing the possessed knowledge. It is even worse, when curious and willing to learn, students suddenly realise they are being stigmatised not because of something they can control but because of the educational environment, which becomes a barrier to their successful learning.

The research conducted by Zhong (2012) confirms that traditional ways of education, applied in a traditional school, build learning barriers to a large number of students and not only to those with SEN but also to the ones without them. Only a small proportion of learners stated that a lecture (24\%) and reading text (16\%) are methods favourable for their learning.

David H. Rose, Anne Meyer-the developers of the UDL approach, as well as their colleagues, model a system of education transferring the principles of flexible and open to everybody environment in architecture (Connell et al., 1997) to the educational environment, emphasising the principle of eliminating barriers to successful learning for all students. Following Vygotsky's $(1962,1978)$ theory of the zone of proximal development and his sociocultural theory as well as research in neuroscience and education, they also develop the principles of learning to learn, which predetermine not only the conscious perception of knowledge and ability to apply it but also the understanding of one's own learning experience in the process, when students become expert learners (Meyer et al., 2014).

Pursuing the implementation of quality inclusive education, the theory of the bioecological model developed by Bronfenbrenner and Ceci (1994) supports the 
ideas of UDL. This theory also emphasises the impact of proximal processes and the environment on human development and on its relationship with the environment: its perception, adoption, and creation. Following the bioecological model and the results of the research organised by the European Agency for Special Needs and Inclusive Education, the Ecosystem of Inclusive Education has been defined and it embraces four levels: (1) individual learner; (2) school; (3) community; (4) national or regional levels. It has been proven that the quality of inclusive education at the first, that is, individual, level is significantly related to the expression of inclusive ideas at all the other levels of the ecosystem (European Agency for Special Needs and Inclusive Education, 2019).

Meyer et al. (2014, p. 3) define UDL as an 'educational approach' that embraces areas related to the functioning of biological education process, curriculum, methods, and educational aids. 'Universal Design for Learning is a framework to improve and optimize teaching and learning for all people based on scientific insights into how humans learn'. ${ }^{1}$ This educational approach offers specific guidelines to the educational community about the implementation of inclusive education, putting into effect the principles provided for in the Salamanca Statement: to acknowledge that every child has a right to learn and achieve results at a level accessible to them; every child is unique; every school must be prepared to respond to a broad and unique variety of children; general education schools must be accessible to children with special needs; and the most efficient schools are those that implement inclusive education (UNESCO, 1994).

\subsection{The Formation of the Conception of Students' Uniqueness in the UDL Context}

In the conception of UDL, the diversity of learners is seen as a natural phenomenon in society because no two learners exist who think in the same way or are distinguished by the same learning style, abilities, and interests (Rapp, 2014). The opinion that differences in learners are predetermined by health condition, social, and cultural peculiarities is significantly elaborated on in this approach. Meyer et al. (2014) state that the research conducted by neuro-researchers shows that the brain structure of students attributed to homogenous groups of leaners still has numerous individual differences, which predetermine different learning operations. However, these differences are not chaotic, and certain regularities are characteristic of them; thus, their manifestation in learning can be predicted as well. It is interesting that considerable individual differences, for example, predetermined by autism syndrome, do not always result in learning problems and, in some cases, they can precondition exceptional abilities.

\footnotetext{
${ }^{1}$ The definition is available in the CAST website: http://www.cast.org/our-work/about-udl.html\#. XygW0ij7RPY
} 
Al-Azawei et al. (2016) highlighted the controversially evaluated perspective of learning styles, which is still applied in schools. Although the evidence about the links of learning styles with cognitive activities of learners is insufficient, the idea that learners can recognise ways of learning or their combinations that are convenient to them encourages the establishment of conditions for a meaningful learning experience.

Due to intensive migration processes, cultural, racial, and linguistic differences have lately become more and more visible (Fontenelle-Tereshchuk, 2020). Migrating for various reasons, people introduce changes to homogeneous school communities and encourage finding ways for quality education and the possibilities of achieving the highest personal results for all (Skourtou et al., 2020). A group of local national minorities acquires significance in the diversity of learners, which, next to the need to introduce varied ways of learning, also raises issues of self-identification (Curcic et al., 2014; Magazzini, 2020; Keskitalo \& Olsen, 2019).

The diversity of learners, according to Arce-Trigatti and Anderson (2018), is a contribution to the development of democracy as it can not only facilitate the dialogue and collaboration of cultures but also accelerate the becoming of social justice, providing not 'some' but all the learners with equal opportunities to learn, to realise their own potential through education, and to create a more inclusive and just future. Therefore, Florian (2019) claims that the problem of focusing on 'some' learners can be solved by seeing the uniqueness of every individual as a basis for diversity of people and evolution of humankind.

\subsection{Conceptualisation of Education Differentiation in the UDL Conception}

Pursuing quality education within the diversity of learners, education differentiation has become one of the most significant criteria for the accessibility of education. However, differentiation is one of the most dangerous components of education for the creation of internal segregation and the stigmatisation of some learners. Florian and Black-Hawkins (2011) and Florian (2019) state that when, due to certain reasons, an educational action is exclusively directed towards some learners, a fact of exclusion is created.

'Differentiated instruction' is the most frequently applied differentiation approach Griful-Freixenet et al. (2020). Tomlinson (2000) claims that the educational needs of an individual learner or a small group of learners comprise the object of differentiated instruction. The construct of this approach consists of four components:

1. Content-what the student needs to learn or how the student will get access to the information

2. Process-activities in which the student engages to make sense of or master the content 
3. Products-culminating projects that ask the student to rehearse, apply, and extend what he or she has learned in a unit

4. Learning environment - the way the classroom works and feels (Tomlinson, 2000, p. 2)

Efficient education through the application of a differentiated instruction approach is achieved when the teacher gives continuous consideration to whom they teach, where, what, and how they teach it (Tomlinson \& McTighe 2006). The teacher, being well aware of the learners whose education has to be differentiated, plans the curriculum and educational methods that are most favourable to the student. But the fact that the teacher's differentiating action is targeted either at a learner individually or at a small group of learners calls for particular attention to be paid to the education organisation when implementing the programme. In cases where education is grounded on a traditional education strategy, a teacher has to allocate individual time to learners taught through differentiated instruction. Research shows that the implementation of education that is oriented towards separate learners causes difficulties for teachers in terms of attention distribution, time planning, and the development of learners' social relations (Kaffemaniené, 2005; Mills et al., 2014; Aas, 2019; Westbroek et al., 2020).

For this reason, instead of focusing on individual support to SEN learners, curriculum and means for its implementation are planned, which allows embracing the diversity of needs and inclinations of the whole group of learners and establishing conditions that result in minimising learning barriers to all learners (Meyer et al., 2014; Sanger, 2020). In other words, there is a transition from being aware of the individual differences of some students to acknowledging the diversity of all the learners, from meeting individual needs to creating a barrier-free educational environment that answers the individual needs of all learners.

Rapp (2014) and Griful-Freixenet et al. (2020) affirm that differentiation based on the UDL principle does not deny the possibility of applying differentiated instruction in cases where the individual needs of learners require it. However, according to Griful-Freixenet et al. (2020), although the problem of balancing differentiated instruction and the application of a barrier-free educational environment still requires a more comprehensive and empirical evidence-based answer, it is completely clear that striving for successful learning of every schoolchild and creating a barrier-free learning environment that is favourable to participation of all the learners, abilities of education differentiation become an essential component of teacher's competence. These abilities are essential criteria for a learner's success and a teacher's professionalism (Swanson et al., 2020). Following Van Boxtel and Sugita (2019) and Galkiené (2018), a teacher-professional applies learner-empowering principles of differentiation in all stages of education, starting with planning, organisation of education and evaluation of learners' progress. 


\subsection{Transformation of Educational Goals in the Contexts of Traditional Education and UDL}

The choice of the education differentiation approach depends on the strategy of education a teacher acknowledges and applies. Teachers who prioritise traditional education, based on the essential goal to provide academic knowledge through a teacher-centred educational approach, according to Aas (2019), tend to focus on individual needs and difficulties. Such teachers link the education of the learners who face difficulties with the application of targeted intervention and correction, which should help the learner to overcome difficulties, even though such difficulties are produced by the same teacher organising education in a traditional way. According to these teachers, the planning of individual education takes too much time, and the implementation of this plan is impossible during regular lessons. Therefore, it is decided in advance that certain lessons are of no use to some learners. This results from the fact that in the system of traditional education, educational goals and ways of their implementation are oriented towards an average learner (Hitchcock et al., 2002).

Meanwhile, Aas (2019) suggests that the teachers distinguished by the contextbased understanding of learners' needs tend to carry out general adaptations while planning a lesson and introduce them not as individual interventions but as an integral part of their lesson plan. According to Swanson et al. (2020), the teachers who base their activity on a student-centred approach strive for quality education for all and everybody (the exceptionally gifted and those with SEN) through the efficiency of suggested methods, education differentiation, cultural relevance, social-emotional learning and relevant content. Teachers applying the UDL strategy are the ones who empower their learners. Rapp (2014) states that by being aware of how and why their students learn, the teacher plans the curriculum in a way that ensures active and equal participation of all the learners in the process of education, versus the experience, when general educational goals are adapted to some learners and implemented at a separate time. According to Meyer et al. (2014), the essential goal in the UDL strategy is not a fact that has to be memorised by a learner, but the process of pursuing the goal in the most appropriate way for them. According to the authors, the flexible use of education methods and aids to attain the set educational goals minimises educational barriers and opens the door for full participation of not only SEN students but also improves learning opportunities for all learners.

\subsection{The Construct of UDL Approach Implementation}

Rose and Strangman (2007) state that the construct of guidelines for the implementation of UDL is based on three anatomically and physiologically different neurocognitive systems that are present in every cognitive act. An educational response 
while prioritising the interaction of recognition, strategic, and emotional networks, and organising education within the UDL approach is determined through the three main UDL principles:

- Provide multiple means of engagement (the 'why' of learning)

- Provide multiple means of representation (the 'what' of learning)

- Provide multiple means of action and expression (the 'how' of learning) (Meyer et al., 2014, p. 51)

These principles serve as a basis for the specific guidelines for UDL implementation formulated by CAST (2018). They consist of three areas that aim at the implementation of every principle. Three checkpoints are suggested in every area that recommend educational variations for the implementation of every principle. Following these guidelines and considering the learners' diversity, teachers design flexible curricula, methods, aids, and environments, encouraging learners to attain challenging goals (Hitchcock et al., 2002; Rose \& Strangman, 2007; Dalton, 2017).

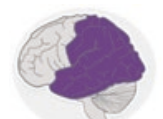

\section{CAST (2018)}

Recognition Networks receive signals coming through sensory organs, and their interpretation enables the recognition of objects and their models (letters, mathematical expressions, historical facts, figures, etc.). Recognition of models embraces all the areas of academic curriculum. Neurological and experiential differences in human cognitive activities predetermine differences in learning activity. Neurological differences are related to individual variations in the structure and function of recognition networks and result in differences in the management of cognitive activities. Experiential differences, i.e. accumulated experience and information stored in memory, allow recognising previously known models anew and reconstructing them. Neurological or physiological problems of recognition networks may lead to a whole range of learning disorders, e.g., dyslexia, dysgraphia, etc. Re-cognition is the main but not the only component of such cognition (Rose \& Strangman, 2007).

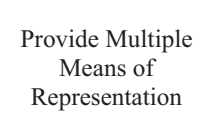

The educational response to neurological differences in human cognitive activity would be providing multiple means of representation. According to Meier and Rossi (2020), learners' informing starts with the formulation of a clear goal. The UDL principle requires the goal to be flexible and achievable by applying various strategies of problem solving and ways of learning. However, Meyer et al. (2014) argue that ways of information perception and learning differ among learners to a big 
extent. These differences are preconditioned by previously acquired basic information, the ability to reproduce this information, to find and use models important for its understanding and to employ ways for perceiving new information. To meet the diversity, a range of ways to present information are employed, using IT and other technologies that help to supplement information with text, language, animation, and image, and using various means of information emphasis and marking. In some cases, it is useful to present the same information with the help of several media, for example, sound and image.

The results of the research by Finnegan and Dieker (2019) evidence the significance of methods applied by the teacher to the perception of information, for example, empowerment of learners to gather information from various sources, to interpret it, to make concept maps, and to verbalise them. Active engagement of learners in the analysis of information leads to a deep and rich understanding and perception of it.

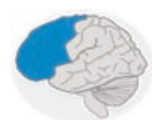

\section{CAST (2018)}

Strategic Networks comprise a set of neuronic networks, which physically and cognitively react to the recognised information models and control an act of complex response to the surrounding world. These networks enable people to plan, coordinate, and independently observe and implement physical movements and cognitive actions. They are related to executive functions of the highest level, which are involved while establishing the goals of activity, developing a strategy for their implementation, observing their implementation and progress or making decisions related to revision of goals, if necessary.

Differences in strategic networks while learning may result in variations in activity implementation at different levels, that is, from ordinary text writing to planning, organisation, creation of alternative ways, and search for support (Rose \& Strangman, 2007).

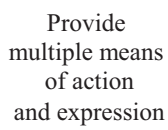

The educational response to neurological differences in human cognitive activity would be providing multiple means of action and expression. Boothe et al. (2018) and Sanger (2020) emphasised that an important stage in the process of successful learning is for learners to express what they have understood and learnt. Two forms of knowledge expression are usually applied: the conveyance of thoughts orally or in writing. However, taking into account variations in schoolchildren's learning 
activities, it is necessary to provide them with the possibility of demonstrating their knowledge and activity results employing other ways as well: through physical expression, communication, artistic solutions, etc. In such cases, when a teacher creates conditions for learners to express themselves in ways favourable to them and chosen personally, it not only becomes possible for learners to efficiently adapt their own knowledge and to express it but also, according to Finnegan et al. (2019), to inform their teacher about how they learn.

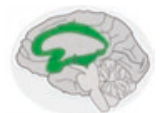

\section{CAST (2018)}

Affective Networks are responsible for decisions to manipulate models that are recognised and generated with the help of recognition and strategic networks. From a neurological perspective, affective networks regulate emotions and activate hormones that have an impact on a biological response, determine our primary emotional state, and form emotional reactions to the surrounding world. Learners' emotions and emotional regulation are very subjective and depend on biological and environmental factors. All of this predetermines differences in how individuals filtrate the world, make decisions, and learn. Following their emotions, motivation, and biological drives, learners establish priorities, maintain their activity if a challenge motivates them, or retreat if a challenge seems to be too difficult. Therefore, according to Vygotsky's (1962) recommendations, it is very important to consider the boundaries of every learners' zone of proximate development because a surmountable task assigned to a learner and accessible educational environment evokes motivation and contributes to achievement of good results. Meyer et al. (2014) claim that learners' involvement in the process of learning is an essential component of efficient learning (Rose \& Strangman, 2007).

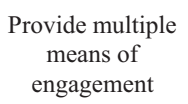

The educational response to neurological differences in human cognitive activity would be providing multiple means of engagement. Schoolchildren's engagement in learning activities is strengthened not only by the compliance between topics and activities and their interests but also by other learning components. According to Hovey and Ferguson (2014), when applying the strategy of research-based learning, the majority of learners express a very positive attitude towards learning. They emphasise very active learning in various environments, collaboration with others and the possibility of sharing relevant ideas. The research by Ramdass and Zimmerman (2008) reveals that teaching children to search for various strategies for 
problem solution and to evaluate their own self-efficacy, and to observe their own progress next to academic teaching, learners' self-regulation and their learning efficiency are strengthened. Ramdass and Zimmerman (2008, p. 37) state that 'classroom practice must not only cultivate the knowledge to succeed but should nurture the belief that one can succeed'. According to Farmer et al. (2018), favourable social relations built up in joint activities are necessary to ensure the learner's success at school. Gay (2013) claims that when the teacher applies culturally responsive teaching in an atmosphere where the diversity of learners is discussed as a value and the emphasis is placed on strengths rather than weaknesses, following the idea that success begets success, the self-confidence of learners with external differences related to their health, social, and cultural status or race is enhanced. This is significant because the research carried out by Farmer et al. (2018) shows that the personal narrative of learners is formed in social relations, which, according to Nieminen and Pesonen (2020), is of utmost importance to students' engagement in learning activities and coping with educational barriers.

\subsection{The Concept of Successful Learning in UDL Approach}

In the contemporary world, the conception of successful learning has acquired a much wider meaning that goes beyond the knowledge learnt. Meyer et al. (2014) emphasise that the learning of the provided content has not lost its meaning, but the emphasis is laid on another goal- to teach students to learn and to become expert learners. García-Campos et al. (2020) point out that the UDL strategy is favourable for encouraging learners to continuously make meaningful, in-depth and emotion-based decisions. After the teacher creates possibilities for constant reflections on their own learning, students' engagement in their own learning is promoted, which leads to the development of 'the motivation, the practice, the reflection, the self-efficacy, the self-regulation, the self-determination, the executive functioning, the comprehension, and the situational awareness' Meyer et al. (2014, p. 15).

Education organised within the UDL approach is grounded on the priority of learners' individuality. Therefore, it is natural that, for this reason, barriers may emerge in the educational environment that prevent certain learners from attaining their set goals. García-Campos et al. (2020) state that UDL is a system that focuses on the elimination of barriers to schoolchildren's learning and participation, suggesting direct and implied actions, which may be used in a varied way. For example, Meier and Rossi (2020) present the following classification of obstacles: (1) skill barriers; (2) curriculum barriers; (3) individual barriers. Planning a specific lesson, the teacher creates the matrices of possible barriers, considering the peculiarities of their learners. The first 'Teaching' matrix includes barriers of the first and second groups and is linked to potential obstacles due to previously acquired knowledge and developed skills, curriculum, or applied methods. The second 'Individual' matrix is related to the individual qualities of a learner. Scaffolds are 
foreseen by the teacher to overcome the learning challenges without simplifying the established goals. In most cases, the successful application of scaffolds according to the first matrix leads to the natural reduction of obstacles assigned to the second matrix.

Al-Azawei et al. (2016) suggest that when education is planned for a diversity of students with UDL from the very beginning, barriers are reduced for schoolchildren with ordinary and special educational needs, and success opportunities are created for all learners.

The development of the skills of an expert in learning is a result of the successful implementation of the UDL principle (CAST, 2018). Consistent application of UDL principles and continuously encouraging reflection on teaching and learning practice together with learners allow the latter to be well aware of their learning process, to constantly improve it, and to engage in joint work of teachers and learners, as well as the evaluation of its results (García-Campos et al., 2020).

The results of scientific research on the assessment of education efficiency reveal that the application of the UDL approach builds learners' self-efficacy and their ability to represent themselves, cultivates their interest in new information and the level of its understanding, as well as their ability to generate, model, and present information in various ways (Capp, 2017). Such learners are characterised by an increased satisfaction, positive attitude and engagement in the learning process (Al-Azawei et al., 2016). When acting together in the learning process, high results are achieved by all students, including learners with special educational needs and exceptionally gifted ones (Katz, 2013).

\subsection{Generalisation: Universal Design for Learning in the Context of Traditional Education}

While pursuing the quality of inclusive education implementation, science, and educational practice are still exposed to problems of interpreting the diversity of learners, balancing the interaction between special and general education, and implementing the philosophy, principles, and practice of inclusive education at school. These issues remain open to the agenda of science and educational practice.

In traditional education system, when fulfilling the needs arising in the diversity of students, the components of individual inclusion prevail. In this case, the focus falls on the students with the most distinct differences in learning abilities, and assistance for them to reach the knowledge and skills outlined in the curricula. The implementation of individual inclusion in the context of traditional education follows the following approach:

- Learners with disabilities, other special educational needs, or exceptional gifts are distinguished by differences in learning activities.

- The reasons for learning difficulties lie in the nature of a learner and in his/her social or cultural experience. 
- Learners' needs comprise the object of education differentiation.

- The goal of education is learning established facts and acquisition of abilities.

- Education is actualised by established learning standards, the results of tests or examinations.

- Teacher-centred education. The teacher sets general and individually adapted educational goals, chooses appropriate methods, and suggests educational aids.

- The teacher and specialists provide necessary help to a specific learner.

Whereas in the case of universal design for learning, the concept of inclusion for all is followed, which is based on the belief that opens possibilities for individual, success-oriented self-expression of all students in the joint process of learning:

- Differences in learning activities are preconditioned by biological, social, and cultural factors and are typical of all the learners. Students with disabilities or exceptionally gifted ones are characterised by more vivid and specific differences, but they make up a part of the same group of learners.

- The reasons for learning difficulties lie in the educational environment, which creates barriers to access necessary knowledge, to recognise objects and their models, to manipulate, construct and design them as well as demonstrate the obtained results.

- The educational environment is the object of education differentiation: educational methods, sources of knowledge, aids - their flexible interaction that ensures barrier-free education for all and leads to the same goal.

- The goal of education is the process of student's learning: fact-finding, critical reflection on them, finding solutions to an assignment or problem, etc.

- Learning when interested and engaged in the process is an essential component of efficient learning. Actualisation of education in the learner's experience is one of the components of pedagogical act.

- The outcome of UDL is to educate and develop a student as an expert in learning. Organisation of child-centred education is directed to encouraging a student to be an active participant in education organisation: contextualisation of learning goals based on own experience and interests, choices of ways of activity and aids, reflection on activity and results.

- Culture of collaboration is implemented through the preparation of the environment that is favourable for collaboration, introducing scaffolds to overcome possible barriers. The teacher is a partner in learner collaboration.

The efficiency of implementing this education approach while developing inclusive education for success of all learners is evidenced by the results of numerous studies (Rao et al., 2020; Katz, 2013; Capp, 2017; Al-Azawei et al., 2016). This education approach, as a scientifically substantiated system of guidelines for educational practice, is included into the federal educational policy in the USA and is suggested to be used as a basis in teacher training and qualification development programmes (Smith et al., 2019). The use of the UDL approach is widespread in the USA. More frequently used concepts in Europe (known as 'Inclusive Design' in the United Kingdom and 'Design for All' in the majority of European countries) define 
the accessibility of the environment and information to all and change thinking about inclusive education as well as the means for its implementation (Clarkson \& Coleman, 2015).

In this action research, the concept of the UDL is understood as an educational approach to the implementation of quality inclusive education. The discussions in the international group of researchers, including pedagogues and researchers engaged in teacher training from four European countries, and Center for Applied Special Technology (CAST) specialists who developed the UDL framework and guidelines, made it clear that when introducing a new approach for inclusive education development at school, the social, cultural, and educational context of the country becomes relevant. Thus, the school in Vienna is already applying individual elements of the UDL in its education system; therefore, to further develop the inclusive education system, it is reasonable to reconceptualise the existing one. In Finland, the model of teachers' inclusive competency development is systematically reviewed. This action research adds elements of UDL approach to the currently developed Finnish teacher competency model, thus expanding and specifying the direction for shaping teachers' beliefs and practices significant to inclusive education. In Poland and Lithuania, inclusive education systems are still affected by the traditional construct of individual inclusion. This causes serious barriers to the development of inclusion for all in the countries. Therefore, the group of Polish researchers resolved to purposefully introduce and analyse the UDL approach in the school education system by applying all three UDL principles. In the study, the research results are presented as three stages in the education process transformation when applying the UDL in the context of continuous change. In Lithuania, a student achievement analysis is continuously carried out, which shows insufficient in-depth learning and its results among students. This action research analyses how expert learner skills are developed by implementing inclusive education through the UDL approach. It focuses on three goals set out in the UDL approach: to educate an expert learner who is resourceful and knowledgeable, strategic, and goal-directed, and purposeful and motivated. Different parts of the action research aimed at revealing different groups of expert learner skills are presented in the study. Overall, the study provides a diversified picture of applying the UDL approach for improving inclusive education, which is valuable in both scientific and practical terms.

\section{References}

Aas, H. K. (2019). Teachers talk on student needs: Exploring how teacher beliefs challenge inclusive education in a Norwegian context. International Journal of Inclusive Education, 1(15). https://doi.org/10.1080/13603116.2019.1698065

Ainscow, M. (2020). Promoting inclusion and equity in education: Lessons from international experiences. Nordic Journal of Studies in Educational Policy, 6(1), 7-16. https://doi.org/10.108 0/20020317.2020.1729587 
Ainscow, M., \& Hargreaves, A. (2016). Collaboration as a strategy for promoting equity in education: Possibilities and barriers. Journal of Professional Capital and Community, 1(2). https:// doi.org/10.1108/JPCC-12-2015-0013

Al-Azawei, A., Serenelli, F., \& Lundqvist, K. (2016). Universal design for learning (UDL): A content analysis of peer reviewed journals from 2012 to 2015. Journal of the Scholarship of Teaching and Learning, 16(3), 39-56. https://doi.org/10.14434/josotl.v16i3.19295

Arce-Trigatti, A., \& Anderson, A. (2018). Defining diversity: A critical discourse analysis of public educational texts. Discourse: Studies in the Cultural Politics of Education, 41(1). https://doi. org/10.1080/01596306.2018.1462575

Booth, T., \& Ainscow, M. (2002). Index for inclusion: Developing learning and participation in schools. Centre for Studies on Inclusive Education (CSIE).

Boothe, K. A., Lohmann, M. J., Donnell, K. A., \& Hall, D. D. (2018). Applying the principles of universal design for learning (UDL) in the college classroom. Journal of Special Education Apprenticeship, 7(3), 1-13.

Bronfenbrenner, U., \& Ceci, S. J. (1994). Nature-nurture re-conceptualized in developmental perspective. A bio-ecological model. Psychological Review, 101(4), 568-586. https://doi.org/ 10.1037/0033-295X.101.4.568

Buchner, T., Shevlin, M., Donovan, M. A., Gercke, M., Goll, H., Šiška, J., Janyšková, K., Smogorzewska, J., Szumski, G., Vlachou, A., Demo, H., Feyerer, E., \& Corby, D. (2021). Same progress for all? Inclusive education, the United Nations Convention on the rights of persons with disabilities and students with intellectual disability in European countries. Journal of Policy and Practice in Intellectual Disabilities, 18(1), 7-22. https://doi.org/10.1111/jppi.12368

Capp, M. J. (2017). The effectiveness of universal design for learning: A meta-analysis of literature between 2013 and 2016. International Journal of Inclusive Education, 21(8), 791-807. https:// doi.org/10.1080/13603116.2017.1325074

CAST. (2018). Universal design for learning guidelines version 2.2. http://udlguidelines.cast.org

Clarkson, P. J., \& Coleman, R. (2015). History of inclusive design in the UK. Applied Ergonomics, 46, 235-247. https://doi.org/10.1016/j.apergo.2013.03.002

Connell, B. R., Jones, M., Mace, R., Mueller, J., Mullick, A., Ostroff, E., Sanford J, Steinfeld, E., Story, M., \& Vanderheiden, G. (1997). The principles of universal design. Version 2.0-4/1/97. NC State University: The Center for Universal Design.

Curcic, S., Miskovic, M., Plaut, S., \& Ceobanu, C. (2014). Inclusion, integration or perpetual exclusion? A critical examination of the decade of Roma inclusion, 2005-2015. European Educational Research Journal, 13(3), 257-267. https://doi.org/10.2304/eerj.2014.13.3.257

Dalton, E. M. (2017). Beyond universal design for learning: Guiding principles to reduce barriers to digital \& media literacy competence. Journal of Media Literacy Education, 9(2), 17-29.

European Agency for Special Needs and Inclusive Education. (2019). Inclusive school leadership: exploring policies across Europe. (E. Óskarsdóttir, V. Donnelly \& M. Turner-Cmuchal, Eds.). Odense, Denmark. https://www.european-agency.org/sites/default/files/sisl_synthesis_report. pdf. Retrieved 16 April 2021.

Farmer, T. W., Dawes, M., Hamm, J. V., Lee, D., Mehtaji, M., Hoffman, A. S., \& Brooks, D. S. (2018). Classroom social dynamics management: Why the invisible hand of the teacher matters for special education. Remedial and Special Education, 39(3), 177-192. https://doi. org/10.1177/0741932517718359

Finnegan, L. A., \& Dieker, L. A. (2019). Universal design for learning-representation and science content: A pathway to expanding knowledge, understanding, and written explanations. Science Activities, 56(1), 11-18. https://doi.org/10.1080/00368121.2019.1638745

Finnegan, L. A., Miller, K. M., Randolph, K. M., \& Bielskus-Barone, K. D. (2019). Supporting student knowledge using formative assessment and universal design for learning expression. The Journal of Special Education Apprenticeship, 8(2), 7.

Florian, L. (2019). On the necessary co-existence of special and inclusive education. International Journal of Inclusive Education, 23(7-8), 691-704. https://doi.org/10.1080/13603116. 2019.1622801 
Florian, L., \& Black-Hawkins, K. (2011). Exploring inclusive pedagogy. British Educational Research Journal, 37(5), 813-828. https://doi.org/10.1080/01411926.2010.501096

Fontenelle-Tereshchuk, D. (2020). Diversity in the classrooms: A human-centered approach to schools. Interchange, 1(11). https://doi.org/10.1007/s10780-020-09402-4

Galkiene, A. (2017). Comparative analysis of legal basis of inclusive education in four European countries. In A. Galkienè (Ed.) Inclusion in socio-educational frames: inclusive school cases in four European countries, 93-99. Lietuvos edukologijos universiteto leidykla. Available at, https://ec.europa.eu/programmes/erasmus-plus/project-result-content/366d374f-25e2-43b292d9-63ad3592cab2/Publikuota-knyga.pdf

Galkienè, A. (2018). Igalinančio ugdymo raiškos edukacinès ịtraukties sąlygomis analizè [Analysis of the expression of empowering education under conditions of educational inclusion]. Pedagogika, 129(1), 77-93. https://doi.org/10.15823/p.2018.06

García-Campos, M. D., Canabal, C., \& Alba-Pastor, C. (2020). Executive functions in universal design for learning: Moving towards inclusive education. International Journal of Inclusive Education, 24(6), 660-674. https://doi.org/10.1080/13603116.2018.1474955

Gay, G. (2013). Teaching to and through cultural diversity. Curriculum Inquiry, 43(1), 48-70. https://doi.org/10.1111/curi.12002

Griful-Freixenet, J., Struyven, K., Vantieghem, W., \& Gheyssens, E. (2020). Exploring the interrelationship between universal design for learning (UDL) and differentiated instruction (DI): A systematic review. Educational Research Review, 29. https://doi.org/10.1016/ j.edurev.2019.100306

Hanreddy, A., \& Östlund, D. (2020). Alternate curricula as a barrier to inclusive education for students with intellectual disabilities. International Electronic Journal of Elementary Education, 12(3), 235-247. https://doi.org/10.26822/iejee.2020358217

Haug, P. (2020). 'It is impossible to avoid policy' comment on Mel Ainscow: Promoting inclusion and equity in education: lessons from international experiences. Nordic Journal of Studies in Educational Policy, 6(1), 17-20. https://doi.org/10.1080/20020317.2020.1730092

Hitchcock, C., Meyer, A., Rose, D., \& Jackson, R. (2002). Providing new access to the general curriculum: Universal design for learning. Teaching Exceptional Children, 35(2), 8-17. https:// doi.org/10.1177/004005990203500201

Hornby, G. (2015). Inclusive special education: Development of a new theory for the education of children with special educational needs and disabilities. British Journal of Special Education, 42(3), 234-256. https://doi.org/10.1111/1467-8578.12101

Hovey, K. A., \& Ferguson, S. L. (2014). Teacher perspectives and experiences: Using projectbased learning with exceptional and diverse students. Curriculum \& Teaching Dialogue, 16(1/2), 77-90.

Kaffemanienè, I. (2005). Pedagoginės sąveikos struktūra ugdant mokymosi negalių turinčius moksleivius bendrojo lavinimo klaseje [Structure of pedagogical interaction when educating pupils with learning disabilities in general classrooms]. Specialusis Ugdymas [Special education], (1), 85-101.

Katz, J. (2013). The three block model of universal design for learning (UDL): Engaging students in inclusive education. Canadian Journal of Education, 36(1).

Keskitalo, P., \& Olsen, T. (2019). Historical and political perspectives on Sámi and inclusive school systems in Norway. In M. C. Beaton, D. B. Hirshberg, G. R. Maxwell, \& J. Spratt (Eds). Including the North: A comparative study of the policies on inclusion and equity in the circumpolar North (pp. 109-123). http://urn.fi/URN:ISBN:978-952-337-136-1.

Magazzini, T. (2020). Integration as an essentially contested concept: Questioning the assumptions behind the national Roma integration strategies of Italy and Spain. In S. Hinger \& R. Schweitzer (Eds.), Politics of (Dis) Integration (pp. 41-59). Springer Open.

Magnússon, G., Göransson, K., \& Lindqvist, G. (2019). Contextualizing inclusive education in educational policy: The case of Sweden. Nordic Journal of Studies in Educational Policy, 5(2), 67-77. https://doi.org/10.1080/20020317.2019.1586512 
Meier, B. S., \& Rossi, K. A. (2020). Removing instructional barriers with UDL. Kappa Delta Pi Record, 56(2), 82-88. https://doi.org/10.1080/00228958.2020.1729639

Meyer, A., Rose, D. H., \& Gordon, D. (2014). Universal design for learning: Theory and practice. CAST.

Mills, M., Monk, S., Keddie, A., Renshaw, P., Christie, P., Geelan, D., \& Gowlett, C. (2014). Differentiated learning: From policy to classroom. Oxford Review of Education, 40(3), 331-348. https://doi.org/10.1016/j.edurev.2019.100306

Nieminen, J. H., \& Pesonen, H. V. (2020). Taking universal design back to its roots: Perspectives on accessibility and identity in undergraduate mathematics. Education Sciences, 10(1), 12. https://doi.org/10.3390/educsci10010012

$\mathrm{Qu}, \mathrm{X}$. (2020). A critical realist model of inclusive education for children with special educational needs and/or disabilities. International Journal of Inclusive Education, 1-15. https://doi.org/ 10.1080/13603116.2020.1760366

Ramberg, J., \& Watkins, A. (2020). Exploring inclusive education across Europe: Some insights from the European Agency statistics on inclusive education. FIRE: Forum for International Research in Education, 6(1), 85-101.

Ramdass, D., \& Zimmerman, B. J. (2008). Effects of self-correction strategy training on middle school students' self-efficacy, self-evaluation, and mathematics division learning. Journal of Advanced Academics, 20(1), 18-41. https://doi.org/10.4219/jaa-2008-869

Rao, K., Ok, M. W., Smith, S. J., Evmenova, A. S., \& Edyburn, D. (2020). Validation of the UDL reporting criteria with extant UDL research. Remedial and Special Education, 41(4), 219-230. https://doi.org/10.1177/0741932519847755

Rapp, W. (2014). Universal design for learning in action. Brooks.

Rose, D. H., \& Strangman, N. (2007). Universal design for learning: Meeting the challenge of individual learning differences through a neurocognitive perspective. Universal Access in the Information Society, 5(4), 381-391. https://doi.org/10.1007/s10209-006-0062-8

Salend, S. J., \& Duhaney, L. M. G. (2011). Historical and philosophical changes in the education of students with exceptionalities. Advances in Special Education, 21, 1-20. https://doi. org/10.1108/S0270-4013(2011)0000021004

Sanger, C. S. (2020). Inclusive pedagogy and universal design approaches for diverse learning environments. In C. S. Sanger \& N. W. Gleason (Eds.), Diversity and inclusion in global higher education (pp. 31-71). Palgrave Macmillan. https://doi.org/10.1007/978-981-15-1628-3

Skourtou, E., Kazoullis, V., Aravossitas, T., \& Trifonas, P. P. (2020). Language diversity in Greece: Local challenges with international implications. Multilingual Education (36) (1st ed.). Springer.

Smagorinsky, P. (2012). Vygotsky, 'Defectology' and the inclusion of people of difference in the broader cultural stream. Journal of Language and Literacy Education [Online], 8(1), 1-25. http://jolle.coe.uga.edu/wp-content/uploads/2012/05/Vygotsky-and-Defectology.pdf. Retrieved 15 March 2021.

Smith, S. J., Rao, K., Lowrey, K. A., Gardner, J. E., Moore, E., Coy, K., Marino, M., \& Wojcik, B. (2019). Recommendations for a national research agenda in UDL: Outcomes from the UDLIRN preconference on research. Journal of Disability Policy Studies, 30(3), 174-185. https:// doi.org/10.1177/1044207319826219

Spencer, J. S., \& Laurel, M. G. D. (2011). Chapter 1. Historical and philosophical changes in the education of students with exceptionalities. Advances in Special Education, 21, 1-20. https:// doi.org/10.1108/S0270-4013(2011)0000021004

Swanson, J. A., Ficarra, L. R., \& Chapin, D. (2020). Strategies to strengthen differentiation within the common core era: Drawing on the expertise from those in the field. Preventing School Failure: Alternative Education for Children and Youth, 64(2), 116-127. https://doi.org/10.1080/ 1045988X.2019.1683802

Takala, M., Pirttimaa, R., \& Törmänen, M. (2009). Research section: Inclusive special education: The role of special education teachers in Finland. British Journal of Special Education, 36(3), 162-173. 
Tomlinson, C. A., \& McTighe, J. (2006). Integrating differentiated instruction \& understanding by design: Connecting content and kids. Association for Supervision and Curriculum Development (ASCD).

Tomlinson, C. A. (2000). Differentiation of instruction in the elementary grades. ERIC Digest. https://files.eric.ed.gov/fulltext/ED443572.pdf

UN General Assembly. (1948). Universal declaration of human rights, 10 December 1948, 217 A (III). Retrieved from https://www.refworld.org/docid/3ae6b3712c.html

UNESCO. (1994). The Salamanca statement and framework for action on special needs education. World Conference on Special Needs Education: Access and Quality. Salamanca. Retrieved from https://www.right-to-education.org/sites/right-to-education.org/files/resourceattachments/Salamanca_Statement_1994.pdf

UNESCO. (2020). Global education monitoring report, 2020: Inclusion and education: all means all. https://unesdoc.unesco.org/ark:/48223/pf0000373718. Accessed 2 Apr 2021.

Van Boxtel, J. M., \& Sugita, T. (2019). Exploring the implementation of lesson-level UDL principles through an observation protocol. International Journal of Inclusive Education (Published online: 20 Aug 2019). https://doi.org/10.1080/13603116.2019.1655596.

Vygotsky L. S. (1993). The fundamentals of defectology (abnormal psychology and learning disabilities). The collected works of L.S. Vygotsky., v. II. Plenum.

Vygotsky, L. S. (1962). Thought and language. MIT Press.

Vygotsky, L. S. (1978). Mind in society. Harvard University Press.

Waitoller, F. R., \& King Thorius, K. A. (2016). Cross-pollinating culturally sustaining pedagogy and universal design for learning: Toward an inclusive pedagogy that accounts for dis/ability. Harvard Educational Review, 86(3), 366-389. https://doi.org/10.17763/1943-5045-86.3.366

Westbroek, H. B., van Rens, L., van den Berg, E., \& Janssen, F. (2020). A practical approach to assessment for learning and differentiated instruction. International Journal of Science Education, 42(6). https://doi.org/10.1080/09500693.2020.1744044

Zhong, Y. (2012). Universal design for learning (UDL) in library instruction. College \& Undergraduate Libraries, 19(1), 33-45. https://doi.org/10.1080/10691316.2012.652549

Выготский, Л. С. (1924). Вопросы воспитания слепых, глухонемых и умственно отсталых детей, под ред. Л.С. Выготского. 1924. № 1. С. 112-120, available at, http://dugward.ru/ library/vygotskiy/vygotskiy_k_psihologii_i_pedagog.html

Open Access This chapter is licensed under the terms of the Creative Commons Attribution 4.0 International License (http://creativecommons.org/licenses/by/4.0/), which permits use, sharing, adaptation, distribution and reproduction in any medium or format, as long as you give appropriate credit to the original author(s) and the source, provide a link to the Creative Commons license and indicate if changes were made.

The images or other third party material in this chapter are included in the chapter's Creative Commons license, unless indicated otherwise in a credit line to the material. If material is not included in the chapter's Creative Commons license and your intended use is not permitted by statutory regulation or exceeds the permitted use, you will need to obtain permission directly from the copyright holder.

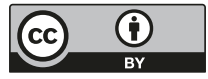

